\title{
Structure of patch-reef fish assemblages at St. Croix, US Virgin Islands, and One Tree Reef, Australia
}

\author{
P. M. Chittaro*, P. F. Sale \\ University of Windsor, Department of Biological Sciences, Windsor, Ontario N9B 3P4, Canada
}

\begin{abstract}
The structure and dynamics of reef fish assemblages on small patch reefs in the Caribbean (St. Croix, US Virgin Islands) were compared with those studied previously (Sale et al. 1994) on the Great Barrier Reef (One Tree Reef), Australia, in order to test whether assemblage structure and function are consistent despite overall taxonomic differences. St. Croix reefs were monitored over 5 yr (1991 to 1996), while those at One Tree Reef had been monitored for 10 yr (1977 to 1986). Analyses of species richness and abundances for individual patch reef assemblages revealed considerable change in assemblage structure between censuses. Specifically, number of individuals and species varied among summer and winter censuses, with summer censuses generally showing greater numbers. Among years but within a season, there was significant variation in the number of individuals (summer and winter) and species richness (summer only) at St. Croix, while only species richness varied yearly (summer and winter) at One Tree Reef. In addition, when the proportional abundances of species observed on each patch reef were compared among censuses on the same patch reefs but at different times (measured as Czekanowski similarity values), results indicated that faunal similarity declined with increasing length of interval between censuses. The mean, betweencensus Czekanowski similarity values for individual assemblages were 0.56 and 0.59 for St. Croix and One Tree Reef, respectively. These results suggest that there is substantial temporal change in assemblage structure at both locations. Species in each location were classified into 12 trophic guilds in order to determine whether the assemblages at St. Croix and One Tree Reef showed similar trophic structure despite different species present. Results indicated that guild structure varied among censuses in both locations and that average guild structure differed substantially between these locations. At St. Croix, diurnal and nocturnal planktivores were proportionately more important, while site-attached herbivores, wide-ranging grazing herbivores, wide-ranging browsing herbivores, sedentary carnivores, and demersal planktivores were proportionately more important on the Australian patch reefs. Results confirm that comparable assemblage dynamics occur for patch reef assemblages at St. Croix and One Tree Reef. However, there are also clear differences in structure and dynamics in these 2 locations, despite the very similar physical and hydrographic habitats occupied.
\end{abstract}

KEY WORDS: Similarity index $\cdot$ Patch-reef fish $\cdot$ St. Croix $\cdot$ Australia $\cdot$ Guilds Resale or republication not permitted without written consent of the publisher

\section{INTRODUCTION}

There are 4 biogeographic regions containing tropical reefs (Indo-West Pacific, Eastern Pacific, Western Atlantic-Caribbean, and Eastern Atlantic) that have had long independent evolutionary histories and consequently share few reef fish species. Yet the processes that have formed the reef environments and their fish assemblages are similar, and we might predict that assemblages that form in similar habitats will be similar in structure and dynamics. Although temporal and spatial comparisons of assemblage structure at meaningful scales are intrinsically valuable, relatively few such examinations exist since they are logistically difficult to accomplish as well as to fund. Notable exceptions include work by Gladfelter et al. (1980) in which patch-reef fish communities at St. Croix and Marshal Islands were monitored from 1976 to 1978; Brock et al. 
(1979) compared the similarity of fish communities at a patch reef in 1966 and again in 1977; Ogden \& Ebersole (1981) examined a large $\left(125 \mathrm{~m}^{2}\right)$ artificial reef from 1975 to 1979 and compared these censuses to that from 1962; and more recently a study by Tupper \& Hunte (1998) on patch and artificial reefs (1 and $100 \mathrm{~m}^{2}$, respectively) in Barbados investigated the temporal and spatial variation in the structure of reef fish assemblages. Ad hoc comparisons based on independent studies are complicated by the fact that different observers collected the data and that ecological methods, such as diversity indices and measures of habitat complexity, vary greatly.

This study uses similarly collected data from patch reefs at One Tree Reef, Australia, and St. Croix, US Virgin Islands, to determine how comparable assemblage structures are, and to what degree they change through time. Data on assemblages occupying lagoonal patch reefs at One Tree Reef (Sale \& Douglas 1984, Sale \& Steel 1986, 1989, Sale \& Guy 1992, Sale et al. 1994) were compared to more recent work conducted using structurally similar patch reefs at Tague Bay, St. Croix, US Virgin Islands. Specifically, we describe the structure of assemblages on physically similar patch reefs at St. Croix and One Tree Reef, and address seasonal and annual patterns of change. In addition, by classifying species into guilds, we were able to determine whether the assemblages show similar trophic structure despite the different species present at the 2 sites.

Table 1. Censusing dates for St. Croix, US Virgin Islands, and One Tree Reef, Australia (taken from Sale et al. 1994)

\begin{tabular}{|c|c|c|c|}
\hline \multicolumn{2}{|c|}{ St. Croix } & \multicolumn{2}{|c|}{ One Tree Reef } \\
\hline Month & Year & Month & Year \\
\hline July $^{\mathrm{a}}$ & 1991 & August & 1977 \\
\hline January & 1992 & December $^{\mathrm{a}}$ & 1977 \\
\hline July $^{\mathrm{a}}$ & 1992 & May & 1978 \\
\hline January & 1993 & August & 1978 \\
\hline July $^{\mathrm{a}}$ & 1993 & November $^{a}$ & 1978 \\
\hline January & 1994 & May & 1979 \\
\hline July $^{\mathrm{a}}$ & 1994 & August & 1979 \\
\hline January & 1995 & April & 1980 \\
\hline July $^{\mathrm{a}}$ & 1995 & April & 1981 \\
\hline \multirow[t]{11}{*}{ January } & 1996 & November $^{a}$ & 1981 \\
\hline & & August & 1982 \\
\hline & & December $^{\mathrm{a}}$ & 1982 \\
\hline & & June & 1983 \\
\hline & & November $^{\mathrm{a}}$ & 1983 \\
\hline & & January $^{\mathrm{a}}$ & 1984 \\
\hline & & August & 1984 \\
\hline & & January $^{\mathrm{a}}$ & 1985 \\
\hline & & August & 1985 \\
\hline & & January $^{\mathrm{a}}$ & 1986 \\
\hline & & July & 1986 \\
\hline${ }^{\mathrm{a}}$ Summe & & & \\
\hline
\end{tabular}

\section{MATERIALS AND METHODS}

Field work was conducted at St. Croix, US Virgin Islands, from 1991 to 1996 (Table 1). At Tague Bay, on the northeast coast of St. Croix, an extensive barrier reef provided a back reef zone 2 to $6 \mathrm{~m}$ deep that contained numerous, chiefly non-emergent, patch reefs. Twenty small, non-emergent reefs were selected for study and were representative of this lagoon area of Tague Bay. In order to permit direct comparisons between St. Croix and Australian data, the protocol for patch reef selection and censusing was taken from the One Tree Reef study (Sale \& Douglas 1984). Physical structure and the environment surrounding patch reefs at St. Croix were comparable to that at One Tree Reef (Sale 1996). Selected patch reefs ranged in size from 2.5 to $31 \mathrm{~m}^{2}$ surface area, and were at a depth of 3 to $4 \mathrm{~m}$ at low tide. In addition, each patch reef was isolated from its nearest neighbour by at least $2 \mathrm{~m}$ of open sand, usually more. Movement of fish between reefs was infrequent, and most individuals were reliably present on single reefs. The size range, depth, and isolation were all similar to those of reefs at One Tree Reef (Sale 1996). Patch-reef fish assemblages (number of individuals of each identified species) were censused through the use of a complete-count visual technique described and evaluated by Sale \& Douglas (1981). Patch reefs were visited 3 times within a period of $1 \mathrm{wk}$. Each visit began with the diver approximately $3 \mathrm{~m}$ away from the patch reef recording the most active species in and around the target patch reef. The diver then proceeded to approach and circle the patch reef, finally close enough to examine crevices. All observed species and their abundances were recorded on an underwater slate. Following the third visit the enumerations were pooled to give a best (maximized) estimate of the fauna actually present (Sale \& Douglas 1981). In total, 10 sets of censuses $\left(2 \mathrm{yr}^{-1}\right.$ over $5 \mathrm{yr}$ ) on each of 20 patch reefs were completed at St. Croix. Twenty sets of censuses (approx. $2 \mathrm{yr}^{-1}$ over $10 \mathrm{yr}$ ) had been conducted on each of 20 patch reefs at One Tree Reef (Table 1). These patch reefs were representative of the lagoon of One Tree Reef. Prior to any analysis, data were tested for homogeneity of variances, heteroscedasticity, and normality.

Analyses of richness and abundance. For patch reefs at St. Croix, species richness and abundance of individuals were examined seasonally and annually to determine the temporal constancy of patch reef assemblages. The null hypothesis was that no variation in number of species nor individuals was expected seasonally or annually. For the seasonal analysis separate 2-way ANCOVAs were conducted for species richness and total abundance of individuals, such that the design was 20 reefs by 2 seasons (summer defined as 
censuses that fall within April to August, and winter was for November to February). The covariate was 'abundance of individuals' when the dependent variable was 'species richness', and 'species richness' when the dependent variable was 'abundance of individuals'. For the annual analysis, a within-season ANOVA with repeated measures was conducted, where years represented the repeated measures. Seasons were analyzed separately in order to select for the year influence only. Equal numbers of replicates of summer and winter seasons were not possible for One Tree Reef (see Table 1). Otherwise, the analyses were comparable.

Temporal dynamics in patch reef assemblages. To examine temporal variability in patch reef assemblages in the Australian data, we had used the Czekanowski proportional similarity index and compared pairs of censuses of single patch reefs. While multivariate approaches are more readily available now than they were in 1980, we have retained this approach to analyse the St. Croix data in order to facilitate comparison between regions. The Czekanowski proportional similarity index compares censuses $i$ and $j$ :

$$
C_{i j}=1-0.5 \sum_{k=1}^{s}\left|P_{i k}-P_{j k}\right|
$$

where $P_{i k}$ and $P_{j k}$ are, respectively, the proportions of individuals in assemblages $i$ and $j$ that are members of the $k$ th species, and there are $s$ species present. Czekanowksi proportional similarity values range from 0.0, when the compared censuses have no species in common (total dissimilarity) to 1.0 , when the proportional distribution of individuals among species is identical (total similarity). This index of faunal similarity accounts for the relative abundance of individuals and is largely insensitive to fluctuations of rare species (Sale et al. 1994). Each faunal similarity value is derived by comparing 2 censuses from a single patch reef. Thus all possible comparisons among 10 and 20 censuses from St. Croix and Australia data sets, respectively, would yield 45 and 190 faunal similarity values, respectively.

Temporal dynamics of St. Croix assemblages. Czekanowski similarity values were used to address whether reef fish assemblages at St. Croix showed temporal variation, both seasonally and annually. The null hypothesis was that assemblage structure was constant through time, meaning that the proportional abundance of individuals of each species was the same across seasons and years. All pairs of censuses of each patch reef were compared (45 comparisons for each reef). Because the number of similarity values for a set of censuses is always larger than the number of censuses in the set (for $n>3$ censuses), we have guarded against an inflation of degrees of freedom in analyses by randomly sub-sampling sets of similarity values to yield a balanced design, with number of similarity values equaling the number of censuses in each treatment (see also Sale et al. 1994).

To test for seasonal variation, census comparisons were classified as within season (summer census compared to another summer census, S-S, or a winter census compared to another winter census, W-W) or between seasons (summer vs winter, S-W). Comparisons were confined to censuses that were separated by a period of 1 yr. A 2-way ANOVA (3 types of comparison, S-S, W-W, S-W; 20 reefs) was used to test the null hypothesis that mean faunal similarity will be similar within and between seasons. Reefs were considered blocks in the design. By randomly sub-sampling we set the design with approximately equal numbers of comparisons per treatment.

To test for variation in structure among years, only within season (S-S and W-W) comparisons were used (20 per patch reef). These were sorted to select those comparing censuses 1 yr apart ( $\mathrm{n}=8$ per reef), and those comparing censuses 3 or more years apart $(n=6$ per reef). These values were compared using a 2-way ANOVA (short- and long-term comparisons, within winter or summer seasons; 20 reefs), where reefs were considered blocks in the design. The null hypothesis was that faunal similarity would not vary with time between censuses compared.

Mean faunal similarity. In order to determine whether dynamics of reef fish assemblages were similar between St. Croix and One Tree Reef, we examined the mean within-reef faunal similarity (the mean across all reefs) for St. Croix among censuses that were adjacent in time, separated by $3 \mathrm{yr}$, and separated by 5 yr. Mean faunal similarity values for One Tree Reef were taken from Sale et al. (1994).

Trophic analysis. In order to determine whether assemblage structure at St. Croix and One Tree Reef showed a similar trophic structure, each species censused was classified into 1 of 12 feeding guilds (Table 2) using published data on diet and our own unpublished observations. After pooling data across patch reefs, we used principal component analysis (PCA) based on a correlation matrix with varimax normalized orthogonal transformation, to compare trophic structure at each census at St. Croix and One Tree Reef. We sought to determine the extent of inter-census variation in trophic structure, as well as the congruence of trophic structure at the 2 regions. To interpret factors and any patterns, variables with a factor loading $\geq|0.3|$ were examined. A variable with factor loading $\geq|0.3|$ accounts for approximately $10 \%$ or more of the variation (Tabachnick \& Fidell 1996). 
Table 2. Defined functional feeding guilds and number

\begin{tabular}{|ll|}
\hline Guild & \multicolumn{1}{c|}{ Guilds recognized as } \\
\hline 1 & $\begin{array}{c}\text { Herbivore: omnivore, site-attached or territorial } \\
\text { grazer or browser }\end{array}$ \\
2 & Herbivore: wide-ranging grazer \\
3 & Herbivore: wide-ranging browser \\
4 & Carnivore: wide-ranging browsing corallivore \\
5 & Carnivore: wide-ranging browser on sessile \\
& Sponges etc. \\
6 & $\begin{array}{c}\text { Carnivore: wide-ranging, feeds on demersal } \\
\text { crustacea, juvenile fish etc. }\end{array}$ \\
7 & $\begin{array}{c}\text { Carnivore: sedentary browser on sessile or } \\
\text { small mobile invertebrates }\end{array}$ \\
9 & $\begin{array}{c}\text { Carnivore: piscivore } \\
\text { Planktivore: mid-water, diurnal plankton } \\
\text { picker }\end{array}$ \\
10 & Planktivore: demersal planktivorous omnivore \\
11 & Planktivore: mid-water, nocturnal plankton and \\
& crustacea \\
12 & Specialist 'cleaner' or parasite on fish \\
\hline
\end{tabular}
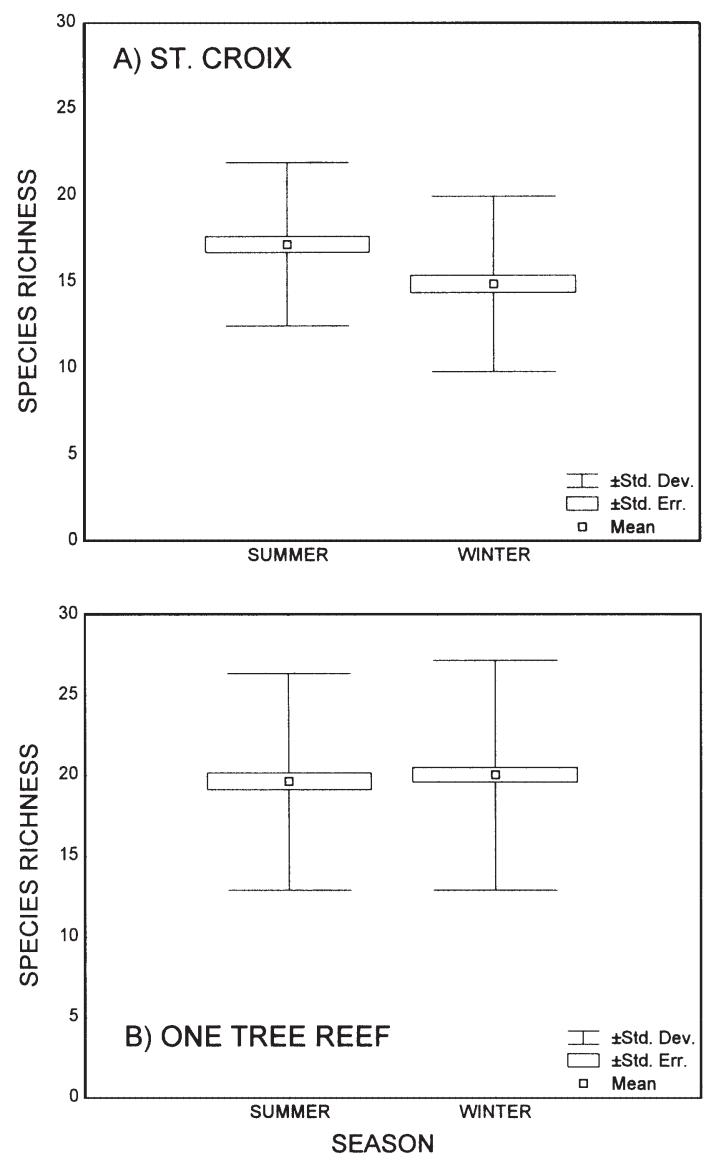

\section{RESULTS}

Over the 5 yr of work at St. Croix, 90 taxa were observed. Most were discriminated to species level, but some species difficult to identify in the field were pooled as 3 single taxa: Coryphopterus glaucofraenum/ Gnatholepis thompsoni, juveniles of Haemulon, and Scarus taeniopterus/S. croicensis. The average number of taxa per patch reef at a census was $16.1 \pm 5.0$ and the average number of individuals per patch reef per census was $111.2 \pm 41.9$. Taxa that accounted for the greatest proportion of individuals were C. glaucofraenum/G. thompsoni (family Gobiidae, 19\%), Haemulon juveniles (family Haemulidae, 17\%), S. taeniopterus/S. croicensis (family Scaridae, 14\%), and Stegastes leucostictus (family Pomacentride, $14 \%$ ).

Over the $10 \mathrm{yr}$ of observations at One Tree Reef, 142 taxa were observed with an average number of taxa per patch reef of 19.8 per census. Again, the majority of taxa were discriminated to species. The average number of
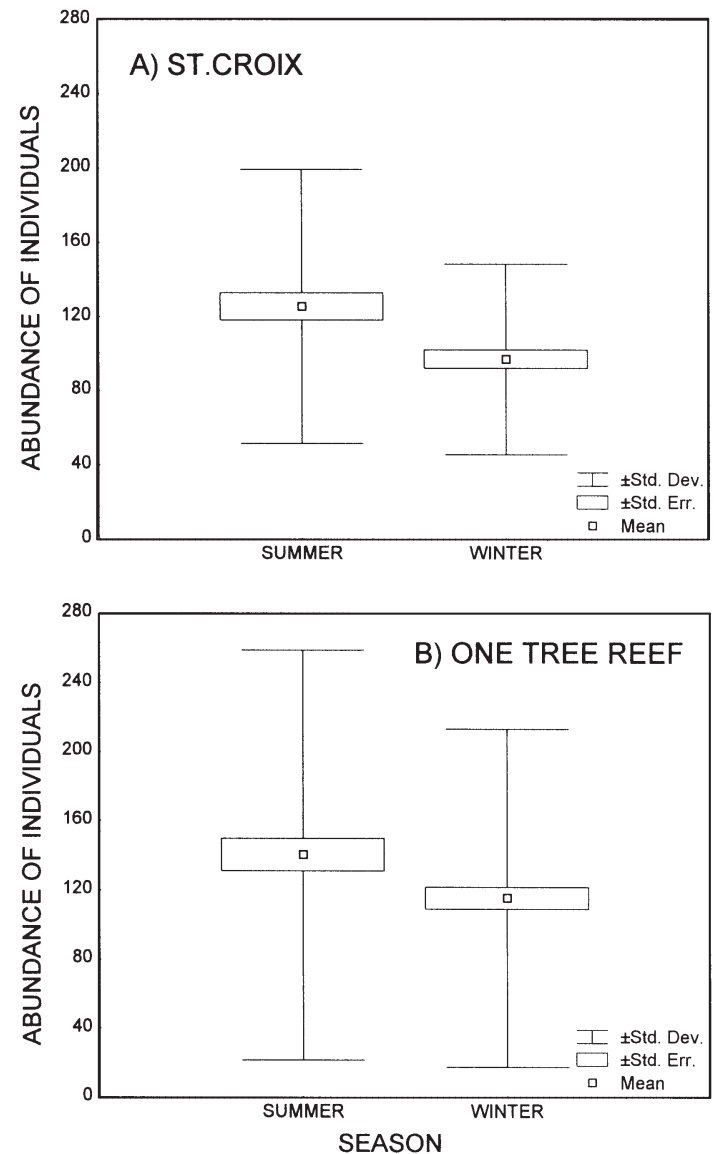

Fig. 1. Box plot of species richness and abundance of individuals per patch reef within winter and summer for 20 patch reefs at (A) St. Croix, US Virgin Islands, and (B) One Tree Reef, Australia. For all comparisons significant differences were observed for the main effect of season 
individuals was $125.3 \pm 73.68$ per patch reef per census. Species that accounted for the greatest proportion of individuals were Apogon doederleini (family Apogonidae, $22 \%$ ), Asteropteryx semipunctatus (family Eleotridae, $13 \%$ ), Acanthochromis polyacanthus (family Pomacentridae, $9 \%$ ), Cheilodipterus quinquelineata (family Apogonidae, 5\%), Amblygobius phalaena (family Gobiidae, $4 \%$ ), and Chromis nitida (family Pomacentridae, $3 \%$ ).

\section{Seasonal analysis of richness and abundance}

For St. Croix, the mean species richness and abundances of individuals was 13 and $23 \%$ greater in summer than winter censuses (Fig. 1A). For One Tree Reef, the mean species richness was $2 \%$ greater in the winter while mean abundance of individuals was $17 \%$ greater in the summer (Fig. 1B). The ANCOVA revealed significant seasonal differences in the abundances of individuals and species at St. Croix, but only in abundance of species at One Tree Reef (Table 3), because of a significant season-reef interaction for individuals at One Tree Reef.

\section{Annual analysis of richness and abundance}

The repeated measures ANOVA for patch reefs at St. Croix indicated that for abundance of individuals there were significant differences among years in both summer and winter censuses, while species richness varied among years only in summer censuses (Table 4, Fig. 2A). At One Tree Reef, there were significant differences among years, regardless of season, for species richness only (Table 4, Fig. 2B).

\section{Similarity analyses of St. Croix assemblages}

If there had been a consistent seasonal shift in assemblage structure, the between season (S-W) comparisons would be less similar on average than comparisons within a season (S-S and W-W). Instead, faunal similarity values determined from comparisons of censuses of the same season and across seasons did not differ predictably (Table 5, Fig. 3A). The interaction between reefs and the type of comparison ( $\mathrm{S}-\mathrm{S}, \mathrm{W}-\mathrm{W}$, and $\mathrm{S}-\mathrm{W}$ ) was highly significant, indicating large differences among reefs. The mean similarities were $0.56,0.55$, and 0.52 for S-S, W-W, and S-W comparisons, respectively.

When faunal similarity values, determined from comparisons of censuses within a season but 1 yr apart, were compared with comparisons of censuses $>3 \mathrm{yr}$ apart, significant differences were observed (Table 5, Fig. 3B). Since no significant duration-reef interaction was observed (Table 5), this decline in similarity with increasing interval suggests that assemblage structure at all patch reefs diverges from its starting point as

Table 3. ANCOVA results comparing abundance of individuals and species richness among summer and winter censuses at St. Croix, US Virgin Islands, and One Tree Reef, Australia. *Statistical significance; ns = non-significant

\begin{tabular}{|c|c|c|c|c|c|}
\hline & Level & df (effect, error) & MS effect & $F$ & $\mathrm{p}$ \\
\hline \multicolumn{6}{|l|}{ St. Croix } \\
\hline \multirow[t]{4}{*}{ Abundance of individuals } & Among seasons & 1,159 & 14087.7 & 6.15 & $<0.05^{*}$ \\
\hline & Among reefs & 19,159 & 6193.84 & 2.71 & $<0.001^{*}$ \\
\hline & Interaction & 1,159 & 2113.6 & 0.93 & ns \\
\hline & $\begin{array}{c}\text { Covariate } \\
\text { (species richness) }\end{array}$ & 1,159 & 39741.7 & 17.35 & $<0.001^{*}$ \\
\hline \multirow[t]{4}{*}{ Species richness } & Among seasons & 1,159 & 130.45 & 11.9 & $<0.001^{*}$ \\
\hline & Among reefs & 19,159 & 62.29 & 5.67 & $<0.001^{*}$ \\
\hline & Interaction & 1,159 & 7.39 & 0.67 & ns \\
\hline & $\begin{array}{c}\text { Covariate } \\
\text { (abundance of individuals) }\end{array}$ & 1,159 & 190.27 & 17.75 & $<0.001^{*}$ \\
\hline \multicolumn{6}{|l|}{ One Tree Reef } \\
\hline \multirow[t]{4}{*}{ Abundance of individuals } & Among seasons & 1,359 & 70671.9 & & \\
\hline & Among reefs & 19,359 & 56802.8 & & \\
\hline & $\begin{array}{l}\text { Interaction } \\
\text { Covariate }\end{array}$ & 19,359 & 10189.7 & 1.85 & $<0.05^{*}$ \\
\hline & (species richness) & 1,359 & 121529 & & \\
\hline \multirow[t]{4}{*}{ Species richness } & Among seasons & 1,359 & 42.6 & 3.92 & $<0.05^{*}$ \\
\hline & Among reefs & 19,359 & 484.41 & 44.57 & $<0.001^{*}$ \\
\hline & Interaction & 19,359 & 12.83 & 1.18 & ns \\
\hline & $\begin{array}{c}\text { Covariate } \\
\text { (abundance of individuals) }\end{array}$ & 1,359 & 240.13 & 22.09 & $<0.001^{*}$ \\
\hline
\end{tabular}


Table 4. Results of the repeated-measures ANOVA which tested for variation among years in assemblage structure, but within a season. * Statistical significance; $\mathrm{ns}=$ non-significant

\begin{tabular}{|c|c|c|c|c|c|}
\hline & Season & df (effect, error) & MS effect & $F$ & $\mathrm{p}$ \\
\hline \multicolumn{6}{|l|}{ St. Croix } \\
\hline Abundance of individuals & $\begin{array}{l}\text { Summer } \\
\text { Winter }\end{array}$ & $\begin{array}{l}5,76 \\
5,76\end{array}$ & $\begin{array}{c}8212 \\
7119.2\end{array}$ & $\begin{array}{l}2.53 \\
5.64\end{array}$ & $\begin{array}{l}<0.05^{*} \\
<0.01^{*}\end{array}$ \\
\hline Species richness & $\begin{array}{l}\text { Summer } \\
\text { Winter }\end{array}$ & $\begin{array}{l}5,76 \\
5,76\end{array}$ & $\begin{array}{c}35.52 \\
9.17\end{array}$ & $\begin{array}{l}3.67 \\
0.68\end{array}$ & $\begin{array}{c}<0.01^{*} \\
\mathrm{~ns}\end{array}$ \\
\hline \multicolumn{6}{|l|}{ One Tree Reef } \\
\hline Abundance of individuals & $\begin{array}{l}\text { Summer } \\
\text { Winter }\end{array}$ & $\begin{array}{l}7,133 \\
9,171\end{array}$ & $\begin{array}{l}7408 \\
5908\end{array}$ & $\begin{array}{l}0.97 \\
1.67\end{array}$ & $\begin{array}{l}\mathrm{ns} \\
\mathrm{ns}\end{array}$ \\
\hline Species richness & $\begin{array}{c}\text { Summer } \\
\text { Winter }\end{array}$ & $\begin{array}{l}7,133 \\
9,171\end{array}$ & $\begin{array}{l}34.33 \\
96.76\end{array}$ & $\begin{array}{l}3.54 \\
4.94\end{array}$ & $\begin{array}{l}<0.01^{*} \\
<0.001^{*}\end{array}$ \\
\hline
\end{tabular}

A) ST. CROIX

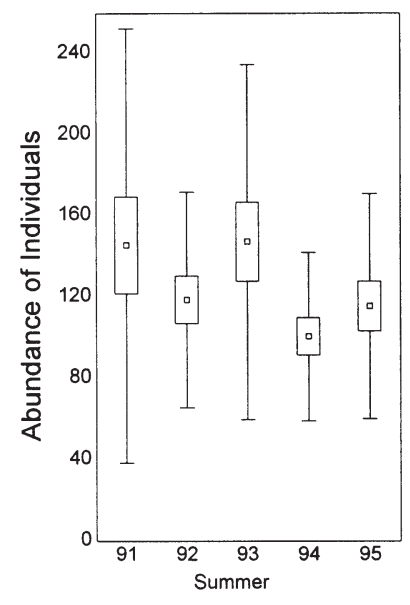

B) ONE TREE REEF

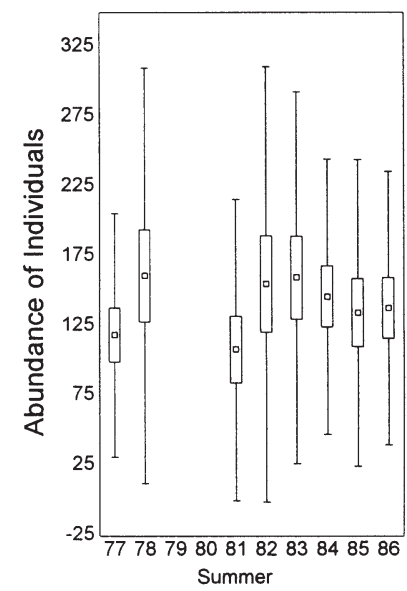

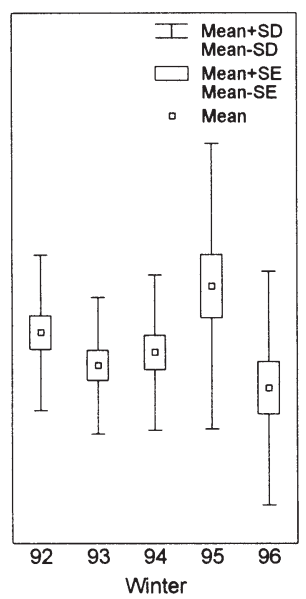

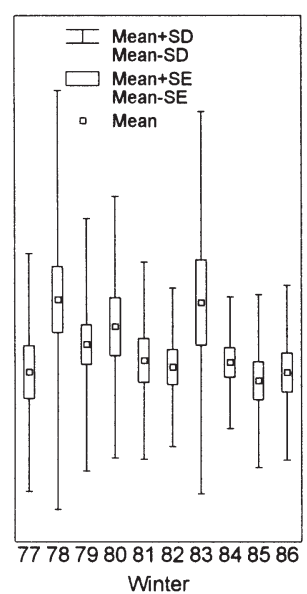

A) ST. CROIX
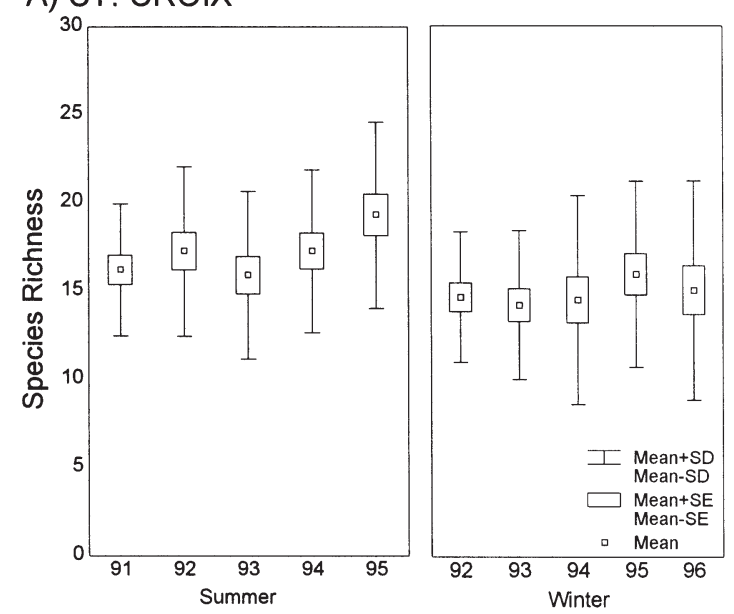

B) ONE TREE REEF
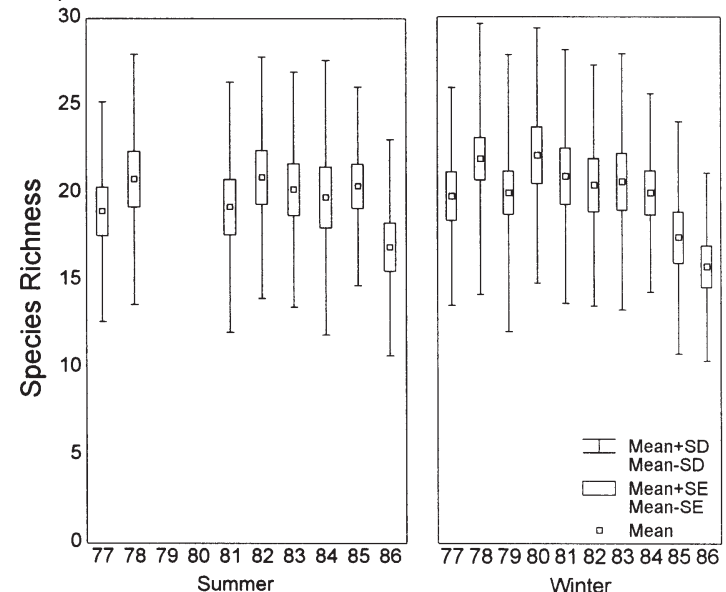

Fig. 2. Box plot of species richness and abundance of individuals per patch reef, across 5 and 10 yr of censuses, for 20 patch reefs at (A) St. Croix, US Virgin Islands, and (B) One Tree Reef, Australia, respectively. No observations were made at One Tree Reef during the summers of 1979 and 1980, and 2 of 20 censuses occurring during spring were not used. Significant differences were observed for St. Croix comparisons of abundance of individuals (both summer and winter) and species richness (only summer), while One Tree Reef showed significant differences for species richness (both summer and winter) 
Table 5. Examination of temporal variability of Czekanowski similarity values for St. Croix assemblages. Two separate analyses were conducted; one investigating whether similarity values produced from same-season census comparisons differed significantly from those from different seasons, and the other addressing whether similarity values differed significantly between 2 temporal

\begin{tabular}{|lcccc|}
\hline & df (effect, error) & MS effect & $F$ & $\mathrm{p}$ \\
\hline Among seasons (S-S, W-W, S-W) & 2,840 & 0.013 & & \\
Among reefs & 19,840 & 0.072 & & \\
Interaction & 38,840 & 0.044 & 2.04 & $<0.001^{*}$ \\
Among durations (1 yr and >3 yr) & 1,240 & 0.116 & 4.9 & $<0.05^{*}$ \\
Among reefs & 19,240 & 0.033 & 1.39 & $\mathrm{~ns}$ \\
Interaction & 19,240 & 0.028 & 1.21 & $\mathrm{~ns}$ \\
\hline
\end{tabular}
intervals. $\mathrm{S}=$ summer; $\mathrm{W}=$ winter $;{ }^{*}$ statistical significance; $\mathrm{ns}=$ non significant

larity values (Czekanowski values). When faunal similarity values were sorted by length of interval between censuses, and the mean values computed across reefs, a coherent pattern was observed. Specifically, at St. Croix the mean faunal similarity decreased and the variability increased as the duration between censuses increased (Table 6, Fig. 4). Unfortunately, at St. Croix the study was too short to determine whether a time was reached when further divergence did not occur. However, the longer data set for One Tree Reef ( $10 \mathrm{yr}$ ) provided information more time elapses. This tendency for assemblage structure to drift away from its prior composition appears to be general for all our patch reefs.

suggesting that the faunal similarity reached a plateau (see Sale et al. 1994) of about $50 \%$ when the interval between compared censuses exceeded 5 yr. This limit may be set by the pattern of recruitment and loss of fish.

\section{Trophic analysis}

Every species of fish observed at each patch reef from St. Croix and One Tree Reef was classified into 1
The degree of temporal change in assemblage structure was assessed through examinations of faunal simi- mporal change at St. Croix and One Tree Reef

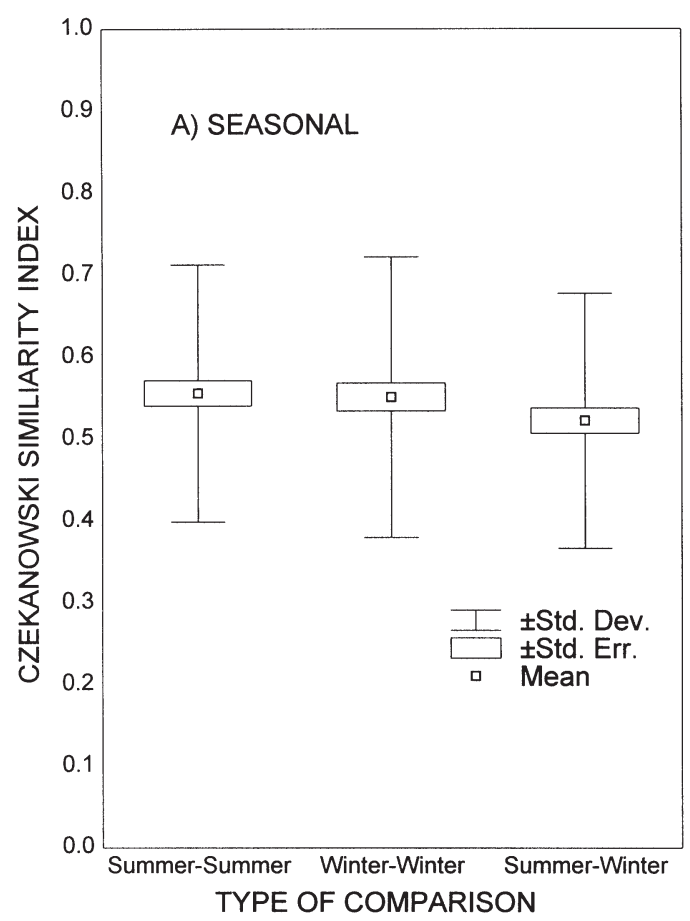

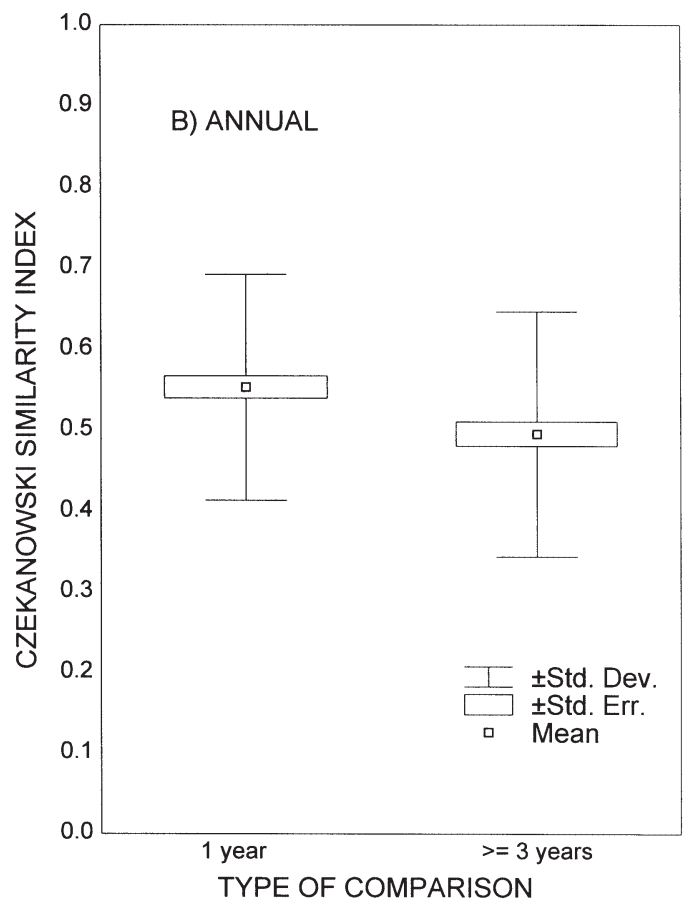

Fig. 3. Box plot of faunal similarity values (Czekanowski's index) for (A) seasonal and (B) annual examinations of St. Croix. The seasonal analysis was across all patch reefs $(n=20)$ and investigated similarity of fish assemblages within seasons (summersummer, $\mathrm{n}=200$, and winter-winter, $\mathrm{n}=200$ ) and between seasons (summer-winter, $\mathrm{n}=520$ ). There was no significant difference among the 3 types of comparisons. The annual analysis investigated faunal similarity for census durations of $1 \mathrm{yr}(\mathrm{n}=160)$ and $>3$ yr $(n=120)$ apart, within the same season. A significant difference was observed between faunal similarity derived from comparison of census pairs adjacent in time versus those $>3 \mathrm{yr}$ apart 
of 12 feeding guilds (Table 2). Fig. 5 illustrates the proportion of individuals within each trophic guild when data from all censuses at each location are pooled. Note that 2 guilds, 4 and 12 (corallivores and cleaners, respectively), accounted for only 1.7 and $0.4 \%$ of individuals at One Tree Reef, and were not represented in the St. Croix data. Therefore these 2 guilds were excluded from the PCA.

The PCA permitted the comparison of trophic structure present on sets of patch reefs at St. Croix and One Tree Reef in a single space defined by 10 guilds. This analysis showed that guild structures were clearly distinct at One Tree Reef and St. Croix (Fig. 6). In addition, guild structure varied substantially from one census to the next, within each region, indicating that the assemblage of fishes occupying patch reef habitat

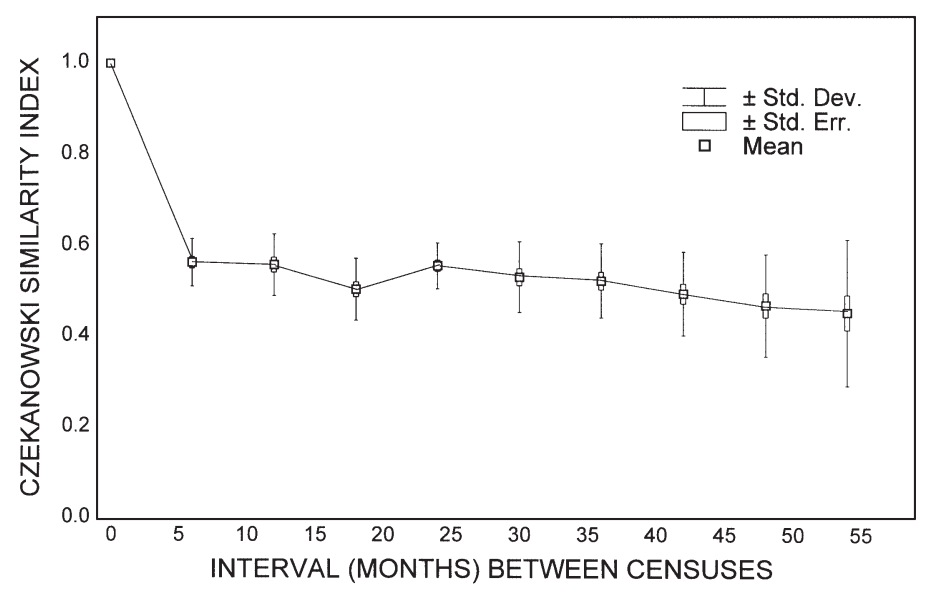

Fig. 4. Trend in faunal similarity (Czekanowski's similarity index) with increasing interval between censuses

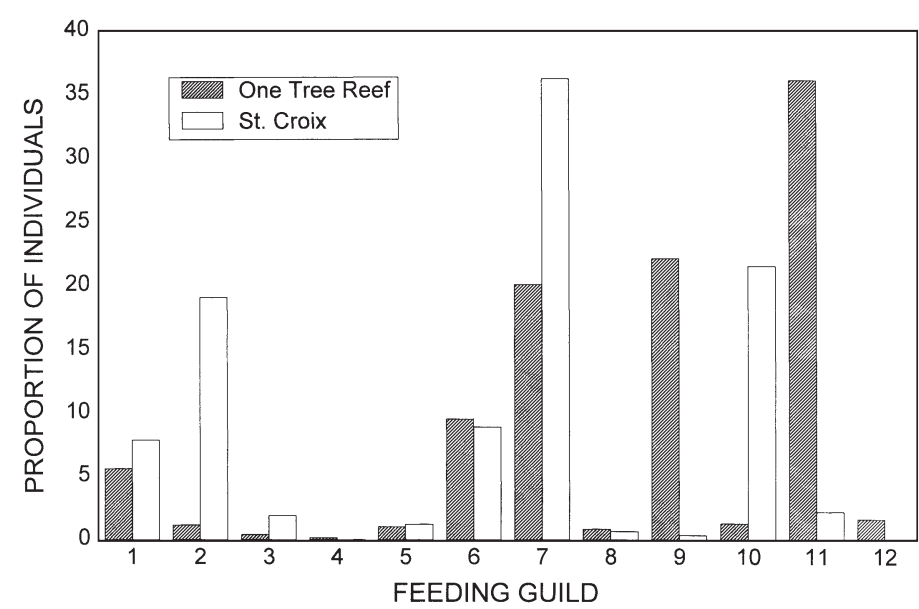

Fig. 5. Proportion of individuals belonging to each trophic guild for St. Croix and One Tree Reef. For trophic guild descriptions see Table 2
Table 6. Mean Czekanowski similarity values among censuses of single patch reefs in St. Croix and One Tree Reef. Mean similarity values were averaged over 20 patch reefs at each site, for the given duration of time. One Tree Reef data summarized from Sale et al. (1994), where 10 randomly selected pairs of censuses for each patch reef were chosen

\begin{tabular}{|lcc|}
\hline Location & $\begin{array}{c}\text { Duration of sampling } \\
\text { period (yr) }\end{array}$ & $\begin{array}{c}\text { Mean similarity } \\
\text { (SE) }\end{array}$ \\
\hline St. Croix & 0.5 & $0.564(0.0112)$ \\
& 3 & $0.527(0.0165)$ \\
One Tree Reef & 5 & $0.453(0.0347)$ \\
& 0.5 & $0.587(0.0867)$ \\
& 3 & $0.568(0.0090)$ \\
& 6 & $0.462(0.0781)$ \\
& 10 & $0.508(0.0403)$ \\
\hline
\end{tabular}

varies trophically over time. This temporal variation involves both Factors 1 and 2, which together account for $63 \%$ of the variation within the data set (Table 7 ). According to the PCA, Guilds 1 (herbivore: omnivore), 2 (herbivore: grazer), 3 (herbivore: browser), 7 (carnivore: sedentary) and 10 (planktivore: demersal) are most important in defining fish assemblage structure at One Tree Reef, while Guilds 9 (planktivore: diurnal) and 11 (planktivore: nocturnal) are most important at St. Croix (Figs. 5 \& 6).

\section{DISCUSSION}

While early ecological theory anticipated that tropical assemblages were in equilibrium, observations during the $70 \mathrm{~s}$ and 80 s revealed that assemblages of coral reef fishes fluctuated on several spatio-temporal scales (Sale et al. 1984, Sale \& Steel 1989, Fowler 1990). It is now understood that the distribution and abundances of fish are influenced by pre- and postsettlement processes which vary in importance through both space and time. Pre-settlement processes include distribution and abundances of sexually mature individuals (Robertson et al. 1988), ocean circulation patterns (Caselle \& Warner 1996, McIlwain 1997, Shapiro et al. 1997, Jones et al. 1999) and larval settling preferences (Victor 1986, Robertson et al. 1988). Post-settlement processes, on the other hand, refer to influences such as competition for limiting resources and predation which determine the numbers and distribution of fish (Sweatman 1985, Letourneur 1996). Since similar processes are expected to influence fish assemblage structure at both One Tree Reef and St. Croix, we questioned whether reef fish assemblages found on patch reefs at both locations are comparable in terms of temporal persistence and 


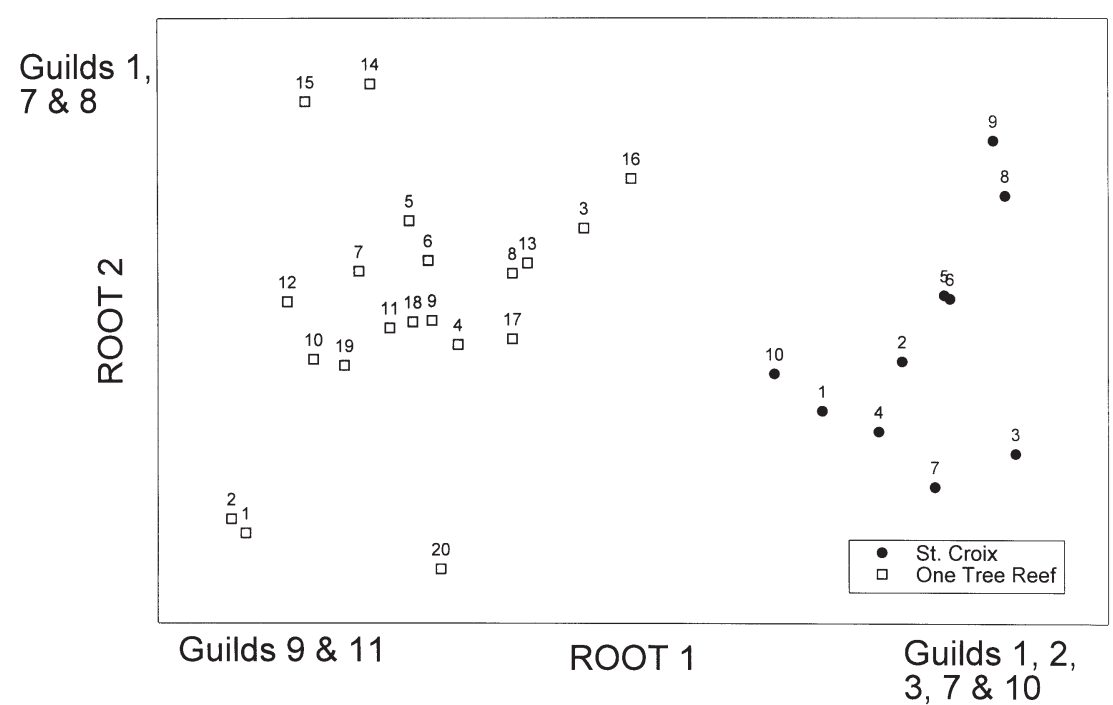

Fig. 6. Assemblage structure at One Tree Reef, Australia, and St. Croix, US Virgin Islands, defined by the principal component analysis (PCA) of feeding guilds. Each census is located in a space defined by the first 2 PCA roots. Numbers indicate specific census periods (refer to Table 1 for the dates of each census). Guilds listed on $x$ - and $y$-axes are those that loaded significantly (positive or negative) on the particular root

trophic structure. This rare opportunity to compare the structure and dynamics of reef fish assemblages in 2 biogeographically different locations was possible because patch reefs at One Tree Reef and St. Croix were similar in physical structure (data are available in Sale \& Douglas 1984, Sale et al. 1994 for One Tree Reef, and in Sale 1996 for both One Tree Reef and St. Croix) and all were sampled using identical census methods. Our analysis first looked at species richness, total abundance of fish, and the proportional abundance of each species. We examined change in these components from census to census, between seasons, as well as across years, and found substantial change in species composition among censuses at both locations.

Specifically, at St. Croix and One Tree Reef the number of species present on any patch reef varied significantly between seasons (Table 3, Fig. 1). A similar observation was noted for the number of individuals at St. Croix. When seasonal effects were removed in order to examine the structure of fish assemblages across years, results indicated that numbers of species and individuals varied over 5 yr at St. Croix (except species richness in winter censuses), and that species richness, but not number of individuals, varied across $10 \mathrm{yr}$ at One
Tree Reef (Table 4, Fig. 2). Inferring assemblage structure only from abundance and richness data is informative but can be misleading. In this case, although variation in the number of individuals was shown to be relatively small (and not significant) among years at One Tree Reef, analyses using the Czekanowski index showed high rates of change in the proportional abundance of species between censuses.

Seasonal patterns in numbers of species and individuals at both St. Croix and One Tree Reef were shown to be similar (greater numbers in the summer), and therefore we asked whether the structure (in terms of the proportional abundances of individuals for each species) of patch reef assemblages varied seasonally and/or annually? If these reefs were closed systems, at or near stable equilibrium, then when 2 censuses of the same patch reef were compared they would likely contain almost identical abundances of individuals and species over any interval of time. Instead, when St. Croix censuses taken in the same or different season but 1 yr apart were compared using Czekanowski's index, just $55 \%$ of the assemblage structure was consistent between the compared censuses (Table 5, Fig. 3A). Faunal similarity was significantly lower with longer durations between compared censuses, suggesting that these systems had not reached a stable equilibrium (Table 5, Figs. 3B \& 4).

Several studies that were conducted at a variety of locations, including different-sized reefs (both natural and artificial), and varying in time between censuses,
Table 7. Factor loadings from the principal component analysis (PCA) of One Tree Reef and St. Croix guild data. Loadings $>|0.3|$ are bold

\begin{tabular}{|c|c|c|c|c|}
\hline Guild & Root 1 & Root 2 & Root 3 & Root 4 \\
\hline 1 & 0.632 & 0.475 & 0.198 & -0.34 \\
\hline 2 & 0.932 & -0.221 & -0.175 & -0.006 \\
\hline 3 & 0.824 & 0.112 & 0.012 & 0.038 \\
\hline 5 & 0.093 & 0.106 & 0.097 & 0.957 \\
\hline 6 & -0.039 & -0.056 & 0.932 & 0.142 \\
\hline 7 & 0.847 & 0.346 & 0.092 & 0.127 \\
\hline 8 & -0.116 & 0.907 & -0.131 & 0.135 \\
\hline 9 & -0.933 & 0.162 & 0.196 & 0.027 \\
\hline 10 & 0.576 & 0.093 & -0.567 & 0.142 \\
\hline 11 & -0.879 & 0.247 & 0.277 & -0.115 \\
\hline$\%$ variance explained & 48.259 & 14.238 & 12.261 & 10.727 \\
\hline Cumulative \% & 48.259 & 62.497 & 74.759 & 85.486 \\
\hline Eigenvalue & 4.825 & 1.423 & 1.226 & 1.072 \\
\hline
\end{tabular}


denudations, or establishment to that of this study, have also noted a lack of similarity in reef fish assemblages through time. For instance, Talbot et al. (1978) noted a lack of faunal similarity over a $3 \mathrm{yr}$ study on artificial patch reefs $\left(0.576 \mathrm{~m}^{2}\right)$ at One Tree Reef. They used Jaccard's Coefficient of Community, which accounts only for species presence or absence, and found that consecutive monthly censuses yielded mean Jaccard values of 0.283 (winter) and 0.238 (summer) indicating substantial replacement of species (values calculated from their Table 8). Brock et al. (1979) defaunated a Hawaiian experimental patch reef $\left(1500 \mathrm{~m}^{2}\right)$ in 1966 and 1977, and showed that the assemblages present on each occasion shared only $40 \%$ of the species. In order to permit comparisons with their own One Tree Reef data, Sale \& Douglas (1984) converted published data from Brock et al. (1979) to Czekanowski similarity values, and reported that the similarity between the 2 collections (1966 and 1977) was 0.682 compared to 0.568 among the first 8 censuses ( 3 yr) of their One Tree patch reefs. Ogden \& Ebersole (1981) noted mean levels of similarity of 0.605 (Coefficient of Community) for 5 visual censuses made over $17 \mathrm{yr}$ on a large artificial patch reef $\left(125 \mathrm{~m}^{2}\right)$ in Little Lameshur Bay, Virgin Islands National Park, USA. Their published data permitted a conversion to Czekanowski similarity values, and their most similar censuses (1977 and 1978) yielded a value of 0.53 (Sale \& Douglas 1984). In Sale \& Douglas (1984) and Sale et al. (1994), patch reef $\left(2.5\right.$ to $\left.31 \mathrm{~m}^{2}\right)$ assemblage structure at One Tree Reef diverged over adjacent censuses (0.587 mean Czekanowski similarity value), while over 8 censuses ( 3 yr) the value was 0.568 and 0.508 after an additional 12 censuses (10 yr total) (Table 6$)$. This was comparable to our St. Croix data since similarity values produced from census comparisons adjacent in time were more similar than those several years apart. Specifically, adjacent censuses at St. Croix indicated mean similarity values of 0.564 , while values were 0.527 for censuses $3 \mathrm{yr}$ apart and 0.453 for the entire 5 yr (Table 6, Fig. 4). In a recent study by Tupper \& Hunte (1998), assemblage similarity also decreased as census periods on the same artificial patch reefs $\left(1 \mathrm{~m}^{2}\right)$ were compared over increasing intervals. For instance, Czekanowski similarity values for patch-reef fish assemblages 4 mo apart varied between 0.320 to 0.788 (mean 0.568), while that for a 7 mo interval was between 0.331 to 0.669 (mean 0.473) (means calculated from their Table 3). All of these studies, including our own at St. Croix and One Tree Reef, indicated that as time passes, individuals (and therefore species) were gained or lost from patch reefs, progressively altering assemblage structure. This therefore suggests that a stable equilibrium is not reached. The variability in assemblage structure exists despite the presence in these assemblages of numerous species with life spans of 5 to $10 \mathrm{yr}$ or more, species showing relatively high fidelity in dispersion, and species showing low levels of fluctuation in numbers (Sale et al. 1994).

Although the faunal composition differed totally between regions, we assigned species to trophic categories in order to determine if the assemblages were trophically similar. Analyses indicated that St. Croix and One Tree Reef patch reefs supported assemblages with substantially different trophic structure, even though both regions included representatives of 10 of 12 feeding guilds (Fig. 5). While it is possible that the St. Croix and One Tree Reef assemblages would be found to be trophically similar if they had been sampled over the same years, we consider this to be most unlikely. We doubt the world is that tightly organized. Instead we suggest our results are an accurate reflection of a substantive difference in trophic organization between the 2 sites. The fish assembled on patch reefs at St. Croix included greater proportions of planktivores and lesser proportions of herbivores then on patch reefs at One Tree Reef (Fig. 6). Despite the similarity in habitat and the availability at both regions of trophically similar species, fish were observed to use patch reefs differently.

At St. Croix, patch reefs support a fauna that is based substantially on plankton productivity, while at One Tree Reef, patch reefs support a fish fauna that relies more heavily on benthic production. As a consequence, nutrients and energy flow on different pathways in the 2 locations.

Independent of this overall trophic difference, the guild analysis also showed substantial variation in guild structure among censuses within both locations. This variation is surprising given that it is based on data pooled across 20 patch reefs at each location (approximately 2000 fish per census). The variation is at the larger scale of a set of nearby patch reefs, rather than at the scale of a single patch reef. Despite our use of this larger scale, the trophic performance of the patch-reef fish assemblage at each location varies considerably through time, and therefore a static description of the food web would be misleading. Contrary to our observations, Brock et al. (1979) argued that trophic structure (defined as number of species in each trophic group) on an isolated patch reef did not change significantly from 1966 to 1977, and was reestablished in 6 mo following defaunation. However, Gladfelter et al. (1992) reported that the relative percentage of fish within each trophic level varied substantially between censuses conducted in 1980 and 1990. Specifically, there was an average change in invertebrate consumer abundances between 1980 and 1990 of $19 \%$, while for herbivores, piscivores, and planktivores there was $28,60.5$ and $69 \%$, respectively 
(calculated from their Table 4). Their observations confirm that the kind of drift in guild structure we have observed is not unusual.

In this comparative study we observed similarities between patch reefs at St. Croix and One Tree Reef in terms of seasonal and annual variation in species richness and abundances of individual fish. We demonstrated that there were similar declining trends in faunal similarity over time for both regions, suggesting that community structure drifts as new individuals recruit and residents die. In addition, the analysis of trophic structure revealed that guild structure also varied through time, although there were consistent overall differences in trophic structure between regions. Consequently, while the processes structuring assemblages at St. Croix and One Tree Reef appear to be the same, and while they generate a similar stochastic, changing structure, these structures, on average, differ at the 2 locations, both in species composition and in the trophic role they play. This difference exists despite the similar environments in which the fish reside.

Acknowledgements. Valuable suggestions by D. Noakes and 4 anonymous reviewers greatly improved the quality of this manuscript. Funding was provided by the National Science and Engineering Research Council of Canada (Grant \# OGP015284) and the National Science Foundation (Grant \# OCE-9018724).

\section{LITERATURE CITED}

Brock RE, Lewis C, Wess RC (1979) Stability and structure of a fish community on a coral patch reef in Hawaii. Mar Biol 54:281-292

Caselle J, Warner R (1996) Variability in recruitment of coral reef fishes: the importance of habitat at 2 spatial scales. Ecology $77(8): 2488-2504$

Fowler AJ (1990) Spatial and temporal patterns of distribution and abundance of chaetondontid fishes at One Tree Reef, southern GBR. Mar Ecol Prog Ser 64:39-53

Gladfelter EH, Bythell JC, Hillis ZM (1992) Changes in fish assemblage structure at Buck Island, St. Croix, US Virgin Islands from 1980-1990: an indication of predictability in coral reef fish assemblages based on known habitat changes? In: Bythell JC, Gladfelter EH, Bythell M (eds) Ecological studies of Buck Island Reef National Monument, St. Croix, US Virgin Islands: a quantitative assessment of selected components of the coral reef ecosystem and establishment of long-term monitoring sites. Part 2, US Department of the Interior, National Park Service Report. Island Resources Foundation and West Indies Laboratory, Teague Bay, St. Croix, US Virgin Islands, p 14-29

Gladfelter WB, Ogden JC, Gladfelter EH (1980) Similarity

Editorial responsibility: Otto Kinne (Editor),

Oldendorf/Luhe, Germany and diversity among reef fish communities: a comparison between tropical western Atlantic (Virgin Islands) and tropical central Pacific (Marshall Islands) patch reefs. Ecology 61(5):1156-1168

Jones GP, Millcich MJ, Emsile MJ, Lunow C (1999) Self recruitment in a coral reef population. Nature 402:802-804

Letourneur Y (1996) Dynamics of fish communities on Reunion fringing reefs, Indian Ocean. II. Patterns of temporal fluctuations. Exp Mar Biol Ecol 195:31-52

McIlwain JL (1997) Hydrodynamic flows and the flux of larval fishes across the crest of Ningaloo reef, Western Australia. Proc 8th Int Coral Reef Symp 2:1133-1138

Ogden JC, Ebersole JP (1981) Scale and community structure of coral reef fishes: a long-term study of a large artificial reef. Mar Ecol Prog Ser 4:97-103

Robertson DR, Green DG, Victor BC (1988) Temporal coupling of production and recruitment of larvae of a Caribbean reef fish. Ecology 69:370-381

Sale PF (1996) Structure and dynamics of reef fish communities: a biogeographical comparison. In: Cody ML, Smallwood JA (eds) Long-term studies of vertebrate communities. Academic Press, San Diego, p 73-97

Sale PF, Douglas WA (1981) Precision and accuracy of visual census technique for fish assemblages on coral patch reefs. Environ Biol Fish 6(3/4):333-339

Sale PF, Douglas WA (1984) Temporal variability in the community structure of fish on coral patch reefs and the relation of community structure to reef structure. Ecology 65 : $409-422$

Sale PF, Guy JA (1992) Persistence of community structure: what happens when you change taxonomic scale? Coral Reefs 11:147-154

Sale PF, Steel WJ (1986) Random placement and the distribution of fishes among coral patch reefs. Mar Ecol Prog Ser 28:165-174

Sale PF, Steel WJ (1989) Temporal variability in patterns of association among fish species on coral patch reefs. Mar Ecol Prog Ser 51:35-47

Sale PF, Douglas WA, Doherty PJ (1984) Choice of microhabitats by coral reef fishes at settlement. Coral Reefs 3: 91-99

Sale PF, Guy JA, Steel WJ (1994) Ecological structure of assemblages of coral reef fishes on isolated patch reefs. Oecologia 98:83-99

Shapiro DY, Appeldoorn RS, Hensley DA, Ray M (1997) Water flow and spawning time in a coral reef fish. Proc 8th Int Coral Reef Symp 2:1121-1126

Sweatman HPA (1985) The influence of adults of some coral reef fishes on larval recruitment. Ecol Monogr 55:469-485

Tabachnick B, Fidell L (1996) Using multivariate statistics, 3rd edn. Harper Collins College Publishers, New York, p 507-546

Talbot FH, Russell BC, Anderson GRV (1978) Coral reef fish communities: unstable, high-diversity systems? Ecol Monogr 48(4):426-440

Tupper M, Hunte W (1998) Predictability of fish assemblages on artificial and natural reefs in Barbados. Bull Mar Sci 62(3):919-935

Victor B (1986) Larval settlement and juvenile mortality in a recruitment-limited coral reef fish population. Ecol Monogr 53:145-160

Submitted: May 7, 2002; Accepted: November 27, 2002

Proofs received from author(s): February 20, 2003 